\title{
THE IMPACT OF CORPORATE CULTURE ON PRODUCTIVITY OF FIRMS IN GHANA: A CASE OF VODAFONE GHANA
}

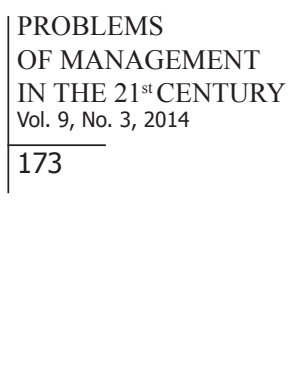

\author{
Godson Ahiabor \\ Central University College, Accra, Ghana \\ E-mail: gkahiabor@yahoo.com
}

\begin{abstract}
It is believed that many of the problems confronting leaders can be traced to their inability to analyze and evaluate organizational cultures. Thus, many leaders, when trying to implement new strategies or a strategic plan leading to a new vision, will discover that their strategies will fail if they are inconsistent with the organization's culture. Organizational culture does not only affect the manner in which managers manage and consequently shape employee behavior, but also the total output and the way it provides services to its customers. Corporate culture or organizational culture is the behavior of humans within an organization and the meaning that people attach to those behaviors. Culture includes the organization's vision, values, norms, systems, symbols, language, assumptions, beliefs, and habits.

In addition, different individuals bring to the workplace their own uniqueness, knowledge, and ethnic culture. Corporate culture covers moral, social, and behavioral norms of one's organization based on the values, beliefs, attitudes, and priorities of its members.

The researcher can say that corporate culture does have a positive impact on the productivity of any organisation, and with Vodafone, it does increase its productivity.
\end{abstract}

Key words: corporate culture, impact, firms, telecommunication and productivity.

\section{Introduction}

Organisations want to obtain the commitment of their employees. Management would like its employees to identify with the values, norms and artifacts of the organisation, hence the need for organisational culture. Management needs to explain what the organisation represents; this will enable the employee to get familiar with the organisational system. During this process of explanation, the employee learns about the organisational culture and decides whether he can cope with it or not. This means that each organisation is a learning environment. Organisational culture and productivity are closely related. Every organisation focuses on increasing their productivity. This productivity can be achieved by building a strong culture that supports teamwork, innovation, commitment and loyalty in order to realise the goal of the organisation. Ignoring strong culture leads to low organisational performance, ethnocentrism, informal grouping and conflict within organisation.

Productivity is an average measure of the efficiency of production. It can be expressed as the ratio of output to inputs used in the production process, i.e. output per unit of input. When all outputs and inputs are included in the productivity measure it is called total productivity

According to most researchers there is a positive relationship between motivation and productivity. That is to say, when motivation increases, we should expect productivity to rise as a result. This is the reflection of the belief that an increase in motivation level causes an increase in productivity - a direct cause and effect relationship. Management trainers accept the belief as an article of faith. 
PROBLEMS

OF MANAGEMENT

IN THE $21^{\text {st }}$ CENTURY Vol. 9, No. 3, 2014

174

One of the key points of Productivity is a result of motivation, and motivation thrives in a good climate. If management is to transform this fragile good climate into a long-lasting culture for success, decision-making structure, organisational integration, human resource development and especially the relationship of management style to culture. Academic interest in corporate culture is evidenced by the level of attention it has received over the last few decades. The relationship between corporate culture and productivity has been the subject of abundant research in several fields, including strategic management, organisational behavior, and industrial organisations. Despite the overabundance of studies on corporate culture in the last few decades, there is no widely accepted causal relationship between corporate culture and productivity or performance within an organisation.

The question of whether corporate culture improves or worsens employee's productivity or performance is still worthy of further research, such as the one being undertaken in this study, and despite the existence of these studies, very little attention has been given to the telecommunication industry in the country. Therefore, this study sought to determine the impact of corporate culture on the productivity of firms in Ghana. This means that the impact of corporate culture on employees' productivity or performance in the telecommunication industry has not received adequate research attention in Ghana.

\section{Literature Review}

This gives an overview of the field of inquiry: what has already been said on the topic and the critical findings, which various researchers have researched and the varied views and opinions based on the specific perspectives and angle that the work is bisected into. Historically, Corporate culture began years back, but was made more popular with the work of writers such as Allen and Kraft (1982), Deal and Kennedy (1982), and above all Peters and Waterman (1982). Nevertheless, Allaire and Firsirotu (1984) showed that, more than twenty years before the work of Peters and Waterman, there was already substantial academic writing on corporate culture. There was an argument between Blake and Mouton (1969) that there was a link between culture and excellence in the late 1960s. Turner (1990) traced the "culture trend" of the 1980 s to the decline of standards in manufacturing quality in the USA and the challenge to its economic pre-eminence by Japan. Turner comments that the concept of culture holds out a new way of understanding organisations, and has been offered by many writers as an explanation for the spectacular success of Japanese companies. Among others, Bowles (1989), observed that there was an absence of a cohesive culture in advanced economies in the West, and that the potential for creating systems of beliefs and myth within organisations provides the opportunity for promoting both social and organisational cohesion.

In the case of culture, it was summed up by Deal and Kennedy (1983), who indicated that culture rather than structure, strategy or politics were the prime movers in organisations. The culture of a group can be defined as "A pattern of shared basic assumptions that the group learned as it solved its problems of external adaptation and internal integration, that has worked well enough to be considered valid and therefore, to be taught to new members as the correct way to perceive, think and feel in relation to those problems" (Schein, 1990). The contemporary definition of organisational culture includes what is valued; the leadership style, the language and symbols, the procedures and routines and the definitions of success that characterise an organisation. It is a specific collection of values and norms that are shared by people and groups in an organisation and that control the way they interact with each other and with stakeholders outside the organisation. "The culture of an organisation affects the type of people employed, their career aspirations, their educational backgrounds and their status in society" (BOLA, 2001).

"The only trustworthy predictor of on-the-job success is how closely an individual work habits match the organisational culture (Giles, 2000). Corporate Culture creates policies and 
assignments to increase profitability and respond to market demands. Having a firm grasp of a company's culture and its degrees gives an executive the advantage. "Understanding and assessing your organisation's culture can mean the difference between success and failure in today's fast changing business environment" (Hagberg \& Heifetz, 2000, It also acts as a facilitator of change- "The power of cultural change is strong, strong enough to turn an aging dinosaur into a state-of-the-art profit-maker. Because people working in different cultures act and perform differently, changing the culture can allow everyone to perform more effectively and constructively" (Taylor, 1991, It helps in Facilitating mergers, joint ventures and acquisitions. Being able to merge and reinvent corporate cultures plays a critical role in national and international takeovers, joint ventures and mergers. If the cultures cannot be merged or reinvented, then the business will fail (Haaland, 2002). Decisions to form joint ventures are made on economic grounds. Their failure to succeed relates to the key non-economic factors, the corporate cultures involved.

It helps in understanding, shaping, nurturing, and proclaiming cultural aspects which increase corporate profitability and growth. "Companies that display specific faces of corporate culture grow 10 times faster than companies that don't. The average net sales growth for so-called high-culture companies is $141 \%$, compared with $9 \%$ growth at "low-culture" companies" (O'Reilly, 2001).

Corporate culture can be identified and analyzed, and there are several consulting firms in North America making significant profits doing just that. Many focus on identifying workforce attitudes, behavioral preferences and the work environment including structure, physical artifacts and communication channels. All agree that attention must be paid to the intangible (unconscious) as well as the tangible (conscious) aspects including the deeply rooted basic assumptions that are often taken for granted by those inside the organisation. Another key indicator is the true reward structure: not what the reward and recognition programs advertise, but how and why people are really rewarded. This is often quite different than the values it verbalises or the ideals it strives for" (Hagber \& Heifetz, 2000). Vodafone is the only total communications solutions provider - mobile, fixed lines, internet, voice and data - and is currently unmatched in providing fixed line and internet services - the leader and the first choice for Ghanaians. Vodafone is the second ranked operator in mobile with a huge potential to take over the market. As a corporate body, it values its customers and constantly builds key relationships with the private sector and government. Its goal is to be the communications leader in an increasingly connected world.

According to Hellriegel and Slocum (1996), organisational culture can enhance performance on a large scale if it can be understood, that is what sustains a culture. According to these authors the culture of an organisation allows the employees to be acquainted with both the firm's history as well as current methods of operation and this specific detection endows the employees with guidance about expected and acceptable future organisational behaviors and norms.

Kotter and Heskett (1992), conducted a study and finds that organisational performance increasing culture or strong culture raised the income of the organisations up $765 \%$ between 1977 and 1988, and only $1 \%$ increase in the same period of time firms without performance enhancing culture (Gallagher, 2008).

Mohammad, Uddin, Huq and Saad (2013) did a study on the impact of organisational culture on employee performance and productivity; the results of these studies mostly show positive association between strong culture and performance improvement. On the basis of this study, they concluded that organisational culture has a positive impact on the employee's job performance. Schein (1990) also stated that organisation's norms and values have a strong effect on all of those who are attached with the organisation. It is considered by him that norms are invisible, but if the organisations want to improve the performance of the employees and profitability, norms are the first places to look at.

\author{
PROBLEMS \\ OF MANAGEMENT \\ IN THE $21^{\text {st }}$ CENTURY \\ Vol. 9, No. 3, 2014 \\ 175
}


PROBLEMS

OF MANAGEMENT

IN THE $21^{\text {st }}$ CENTURY Vol. 9, No. 3, 2014

176

\section{Methodology of Research}

This outlines the procedure in which the data needed for this project to be effective was obtained. In order for this to go through, the researcher constructed a series of questions in the form of questionnaires and interviews and delivered them to two offices of Vodafone Ghana. The target population of the study comprised of 100 staff and clients of Vodafone Ghana in the Accra Metropolitan Area, Airport City and The Accra Mall to be precise. The company was chosen because, prior to its privatisation, it used to be the only state-owned majority shareholder. This facilitated the researcher in achieving his objectives in determining how the corporate culture changed and especially how it affected productivity.

\section{Research Design}

To ensure that an adequate number of responses would be received, the researchers used simple random sampling to collect data. This sampling technique was chosen relative to the others because it is easily understood. The sample results may be projected to the target population and there was no (human) interference in the selection of the sample.

\section{Population}

Target population was selected from two branches of the company, the Headquarters and the Accra Mall branch. Here, the emphasis was on staff and customers of Vodafone. These targets helped reveal the relevance of corporate culture and the impact it creates on the firm as a whole and the customers.

\section{Sample Size}

A sample size of one hundred (100) respondents of both genders was selected. This was limited to the head office only. These were made up of thirty-six (36) staff and sixty-four (64) customers of Vodafone Ghana.

\section{Data Collection Procedure}

Primary Data

The primary source of data collection consisted of direct face-to-face interviews with people who have had contacts with Vodafone directly and indirectly. These included staff of Ghana Telecom/ Vodafone at various positions and day-to-day customers. Appointments were fixed with interviewees and confidentiality was assured before the interviews were conducted in a focused and conversational manner. The framework for the interviews was guided by semi set of questions listed in Appendix B. Questionnaires were also used as primary data collection. These were developed based on the stated objectives and hypothesis. Both open-ended and close-ended questions were used, where the close-ended questions were on a 5-point Likert scale. The scores were coded 5 for strongly agree or very good or very frequent or very impressed; 4 for agree or good or frequent or impressed; 3 for undecided or barely acceptable or rarely or moderately impressed; 2 for disagree or poor or very rarely or not impressed; and 1 for strongly disagree or very poor or never or strongly not impressed. Dichotomous questions like yes or no, before or after, and low, medium and high were also used, where no, before and low will be coded 1, medium will be coded 3 and yes, after and high will be coded 5. Observation was another source of primary data used in collecting information. 
As the researchers spent time in the organization with both staff and customers, they observed how Vodafone Ghana runs its business; the kind of jargon used; the dress code of

PROBLEMS OF MANAGEMENT IN THE $21^{\text {st }}$ CENTURY Vol. 9, No. 3, 2014 employees; the gadgets used in making work efficient; the interrelationship among co-workers; whether working hours were followed accordingly; and if any kind of melodious interlude was played in the background and the kind of genre was played, if played. Observation was also on how the customers reacted to Vodafone's environment and culture, and how satisfied they were if facial expression showed.

\section{Instrument}

Sets of questionnaires and interviews were presented and granted by the management and staff of Vodafone Ghana. Both open-ended and close-ended questions were used as well as 5-Likert point and dichotomous questions in analysing data. In addition, direct face-to-face interviews were held with some of the Vodafone's staff and customers.

Upon completion of questionnaires and interview questions, a pilot survey was made to people not related to Vodafone in any way, and feedback was received in whether questions were ambiguous or difficult. The feedback was that the questions were easy to understand and answer, and few changes were made based on received input.

\section{Data Analysis}

The questionnaires were designed such that it was easy to see if respondents were consistent in their responses and if they understood the questions.

To interpret the data from the Likert Scale, the researchers used the weighted mean to compute the data from the scale and tabulate it. After the tabulation, they gave a graphical presentation before stating the weighted mean of the answers. Percentages of respondents that chose a particular answer-option to a question were then calculated for each question.

\section{Results of Research}

This chapter presents the findings from the distribution of the questionnaires and interviews made to the staff and customers of Vodafone Ghana. The level of living and running the company's brand values.

The level of living and running the company's brand values was categorised under the following distribution:

Table 1. Level of running and living the company's brand values.

\begin{tabular}{llll}
\hline Opinions $(\mathbf{X})$ & Frequency $(\mathbf{Y})$ & $\mathbf{X Y}$ & Percentage \% \\
\hline Strongly Not Impressed (1) & 3 & 3 & 4.84 \\
\hline Not Impressed (2) & 6 & 12 & 9.68 \\
\hline Moderately Impressed (3) & 20 & 60 & 32.26 \\
\hline Impressed (4) & 29 & 116 & 46.77 \\
\hline Strongly Impressed (5) & 4 & 20 & 6.45 \\
\hline Total $(\Sigma)$ & 62 & 211 & \\
\hline
\end{tabular}

Source: Field data, 2014

to find the mean, $=\sum x y / \sum y$, Therefore $=211 / 62=3.40=3=$ moderately Impressed 
PROBLEMS OF MANAGEMENT IN THE $21^{\text {st }}$ CENTURY Vol. 9, No. 3, 2014

There is satisfaction with the values and norms to the Stakeholders

Various opinions were brought out by respondents. These opinions have been categorized into the following:

From the calculation of the average mean above, it was found that the average responses resulted to undecided. The graphical representation in Figure 1 showed that $41 \%$ of respondents agreed that stakeholders are satisfied with the values and norms of Vodafone. A $65 \%$ strongly agreed with the above statement, $14 \%$ disagreed, and $2 \%$ strongly disagreed.

Table 2. Distribution of satisfaction with the values and norms to stakeholders.

\begin{tabular}{lllll}
\hline Opinions $(\mathbf{X})$ & & Frequency $(\mathbf{Y})$ & $\mathbf{X Y}$ & Percentage \% \\
\hline Strongly Disagree & $(1)$ & 2 & 2 & 2.15 \\
\hline Disagree & $(2)$ & 7 & 14 & 7.53 \\
\hline Undecided & $(3)$ & 28 & 84 & 30.11 \\
\hline Agree & $(4)$ & 38 & 152 & 40.86 \\
\hline Strongly Agree & $(5)$ & 13 & 65 & 13.98 \\
Total $(\Sigma)$ & & 93 & 317 & \\
\hline
\end{tabular}

Source: Field data, 2014

Impression of customers on customer service and culture

This survey was made to find out if customers were fascinated with Vodafone's customer service and customer care, and of course, with their values and beliefs.

Table 3. Distribution on impression of customers on customer service and culture.

\begin{tabular}{lllll}
\hline Opinions (X) & & Frequency $(Y)$ & XY & Percentage \% \\
\hline Strongly Not Impressed & $(1)$ & 3 & 3 & 4.84 \\
\hline Not Impressed & $(2)$ & 6 & 12 & 9.68 \\
\hline Moderately Impressed & $(3)$ & 20 & 60 & 32.26 \\
\hline Impressed & $(4)$ & 29 & 116 & 46.77 \\
\hline Strongly Impressed & $(5)$ & 4 & 20 & 6.45 \\
\hline Total $(\Sigma)$ & & 62 & 211 & \\
\hline
\end{tabular}

Source: Field data, 2014

to find the mean, $=\sum \mathrm{xy} / \sum \mathrm{y}$ Therefore $=211 / 62=3.40=3=$ moderately Impressed

From the mean calculated above, the students were able to deduce that respondents were moderately impressed with the customer service and culture of Vodafone.

With this information and the one from the Satisfaction with Values and Norms to Stakeholders (4.8), the researchers accumulated that the 'Vodafone Way' would be preferred in other organizations. They believed that if Vodafone was able to improve in such a fast pace, then other firms can improve too if they adapt to a similar culture. 
Distribution on impression of customers on customer service and culture

Figure 2. The researchers realised that $47 \%$ of the respondents were impressed with the services and culture of Vodafone. This was followed by moderately impressed with $32 \%$. Ten respondents, that is, $10 \%$ of respondents were not impressed with Vodafone's way of running their business. $6 \%$ were strongly impressed and 5\% were strongly not impressed. With this information the researchers generated that Vodafone's customers were satisfied with the 'Vodafone Way' and therefore kept on patronising the company, leading its productivity to increase.

\section{Opinion on Reliability and Transparency}

This survey was conducted by asking Yes or No questions. Below is a tabulation of the various answers and their graphical representation.

Table 4. Distribution on reliability and transparency of Vodafone.

\begin{tabular}{lllll}
\hline Reliability and Transparency $(X)$ & Frequency $(Y)$ & $X Y$ & Percentage \% \\
\hline No & $(1)$ & 8 & 8 & 12.90 \\
\hline Yes & $(3)$ & 54 & 162 & 87.10 \\
\hline Total $(\Sigma)$ & & & \\
\hline
\end{tabular}

Source: Field data, 2014

The mean for this finding is $=\sum x y / \sum y=170 / 62=2.74=3=$ Yes Customers $(87 \%)$ thought that Vodafone was reliable and transparent to deal with.

\section{Discussion}

It is with no doubt that Vodafone Ghana is one of the leading telecommunication companies in Ghana now. Privatisation has been good for the company and the economy as well.

Though workers were laid off, Vodafone Ghana is still noted for its efficiency, effectiveness, reliability, responsiveness and trust in providing its services. Organisational culture plays an important role in the company, and it is highly practiced in every sense of its operations. Its brand name is driven by what they say and what they do. By paraphrasing most customers' comments on the privatisation of Ghana's only State-owned telecommunication company, it was said that Vodafone Ghana has affected the improvement in services and introduction of new products. The Group has pushed up the whole Ghana Telecom to an international standard.

During Ghana Telecom's era, productivity was low as there were too many technical problems, laziness, and high redundancy.

GT was never able to meet the goals set at the beginning of the year. This meant that there was no productive output when calculating the level of productivity. Since Vodafone took charge, productivity has been increasing massively and customer complaints have reduced drastically. According to Joy FM (10th November, 2011), Vodafone Ghana had recorded 32.5\% growth in half year service revenue, ending September, 2011. This was contained in the Vodafone Group's half year financial report dated November 8, 2011 posted on the group's website. Vodafone Ghana posted some $27.1 \%$ growth in service revenue in the first quarter of the group's financial year ending June, 2011, so the half year results indicated an impressive improvement of 11.4 percentage points. The report attributed Vodafone Ghana's performance to increase in subscriber base and the improved services on the back of the launch of $3.5 \mathrm{G}$ services in June, 2011. 
PROBLEMS

OF MANAGEMENT IN THE $21^{\text {st }}$ CENTURY Vol. 9, No. 3, 2014

180

(NCA) indicated Vodafone was fast closing in on the second biggest operator in Ghana, Airtel. Vodafone had come from 13\% market share in 2009, when it entered the Ghanaian market, to $19.1 \%$, ending September, 2011, which was just $0.5 \%$ away from the second place, Aitel's 19.6\%. Vodafone Ghana has gained lots of customers on the back of Mobile Number Portability (MNP). Vodafone Ghana makes sure that employees work in serenity and in return the staff does their job with accuracy and flexibility. The lower and middle level employees are not allowed to partake in decision making. That is absolutely management's duty. Nonetheless, at every quarter of the year a meeting is held, and at this gathering each team is represented, and suggestions or ideas from all employees are displayed, then if they are good enough, they are taken into consideration by top management.

According to the interviewees, the ideas are implemented more than often. Another reason for Vodafone to be one of the preferred networks in the country is because it contributes to the development of Ghana's agenda through the Vodafone Foundation. It gives out scholarships; assists NGOs; and provides career opportunities for whoever looks for employment with them. Certainly, Vodafone's environment is truly conducive.

Investigation of the research reveals that the output has increased and the market share has also risen. Furthermore about $87 \%$ of respondents said Vodafone was reliable. The study confirms that corporate culture had a positive impact on productivity. This confirms other studies by Hellriegel and Slocum (1996) (Gallagher, 2008). Schein (1990) and Mohammad, Uddin, Huq and Saad (2013).

The view on the impact of corporate culture on productivity is relevant for expansion of output; therefore it adds insights on the topic. The hypothesis that corporate culture does have a positive impact on the level of productivity of firms is proven to be right. This work gives an empirical starting point on the subject matter, and it can serve as a base for further research. The results suggest a link between productivity and organizational culture, and how the impact of the latter affects a corporation or a brand. However, the mainly investigated is the head office but it will be interesting to look at the other regions as well. Moreover, a comparative study can be looked at for further research.

\section{Conclusions}

Culture is not static. As the external and internal factors that influence culture change, so culture will change. However, culture change will be slow, unless there is some major shock to the organisation (Burnes, 1991). This in itself may not be a problem, if other factors also change slowly. In addition, like Handy (1986), Allaire and Firsirotu (1984) argued that, to operate effectively and efficiently, an organisation's culture needs to match or be appropriate to its structure. Changing the way everyone within a business work not only reduces costs, but improves productivity and speed to market. It also helps an organisation attract, and get the most out of the new, technologically literate, Generation Y. But adopting a new way of working is not easy, it demands buy-in from all layers of an organisation.

Now, Vodafone Ghana won six (6) out of seventeen (17) competitive awards at the Second Mobile World Ghana Telecom Awards held on Friday 20th April, 2012 at the Holiday Inn Hotel's premises. Some of the awards included the prestigious Telecom Chief Executive of the year. Vodafone took home the Telecom Brand of the Year award, which was also won the previous year, the Customer Service of the Year and Marketing Campaign of the Year awards, beating strong rivals MTN and Airtel. Other awards taken were the Best Business/ Enterprise Service of the Year, which went to Vodafone Business Solutions and also the Best Female Technologist Award. In conclusion, the researcher can say that corporate culture does have a positive impact on the productivity of any organisation, and with Vodafone, it does increase its productivity. 


\section{References}

Adeyoyin, S. O. (2005). ICT literacy among the staff of West African University libraries: A comparative study of Anglophone and Francophone countries. The Electronic Library (in press).

Allaire, Y., \& Firsirotu, M. E. (1984). Theories of organizational culture. Organization Studies, 56, 7997.

Allen, F. R., \& Kraft, C. (1982). The organizational unconscious: How to create the organizational culture you want and need. Englewood Cliffs, NJ: Prentice-Hall.

Ambler, G. (2008). The practice of leadership. Retrieved from: http://www.thepracticeofleadership.net

Armstrong, M. (1991). A handbook of personnel management practice (4 ${ }^{\text {th }}$ Ed.). London: Kogan Page.

Blake, R. R., \& Mouton, J. S. (1969). Building a dynamic corporation through grid organization development. Reading, MA: Addison-Wesley.

Business Open Learning Archive (BOLA). (2001). What is this thing called organizational culture. Retrieved from: http://www.sol.brunel.ac.uk/ jarvis/bola/culture/culture.html

Bowles, M. (1989). Myth, meaning and work organization. Organization Studies, 10 (3), 405-423.

Burnes, B. (1991). Managerial competency and new technology: Don't shoot the piano player - he's doing his best. Behaviour and Information Technology 10 (2), 91-109.

Deal, T., \& Kennedy, A. (1982). A corporate culture. Reading: Adison-Wesley.

Deal, T., \& Kennedy, A. (1983). Culture: A new look through old lenses. Journal of Applied Behavioural Science, 19 (4), 497-507.

Denison, D. R., \& Mishra, A. K. (1995). Toward a theory of organizational culture and effectiveness. Organization Science, 6 (2), 204-223.

Devis, L. (2007). Organizational culture and its importance. Retrieved from: http://www.organizationalculturecenter.com/.

Fakhar, S., Rana, A. L., Ayesha, R. K., \& Lalarukh, S. (2012). Impact of organizational culture on organizational performance: An overview. Interdisciplinary Journal of Contemporary Research in Business, 3 (9), 975-985.

Frost, P., Moore, L. F., Louis, M. L., Lundberg, C. C., \& Martin, J. (1985). Organizational culture. Beverly Hills: Sage.

Gallagher, E. (2008). Equal rights to the curriculum many languages one message. Clevedon: Multilingual Matters.

Giles, R. (2000). Identifying and influencing organizational culture. Retrieved 10/12/2005from: http:// www.alliesconsulting.com/resources/articles/idinflcult.html.

Haaland, S. (2002). Denison organizational culture survey: Description of norms. Ann Arbor, MI: Denison Consulting.

Hagberg, R., \& Heifetz, J. (2000). Corporate culture lorganizational culture: Understanding and assessment. Retrieved 3/08/2001 from: http://www.hcgnet.com/html/articles/understanding-Culture/ html.

Handy, C. (1986). Understanding organizations. Penguin: Harmondsworth.

Hellriegel, D., \& Slocum, J. W. (1996). Management ( $7^{\text {th }}$ Ed). South Western College Publishing.

Kotter, J. P., \& Heskett, J. L. (1992). Corporate culture and performance. New York: Free Press.

Meyer, J. P., Stanley, D. J., Herscovitch, L., \& Topolaytsky, L. (2002). Affective, continuance, and normative commitment to the organization: A meta-analysis of antecedents, correlates, and consequences. Journal of Vocational Behaviour, 61, 20-52.

Mohammad, J. U., Rumana, H. L., \& Saad, M. H. (2013). Impact of organizational culture on employee performance and productivity: A case study of telecommunication sector in Bangladesh. International Journal of Business and Management, 8 (2), 63-77.

Mowday, R. T., Porter, L.W., \& Stress, R. M. (1979). The measures of organizational commitment. Journal of Vocational Behaviour, 22 (8), 90-96.

Likert, R. (1961). New patterns of management. New York: McGraw-Hill.

O'Reilly, C. (2001). Corporations, culture and commitment. California Management Review, 31 (4), 9-23.

Payne, R. L., \& Pugh, D. D. (1976). Organizational structure and climate. In M. Dunnette (Ed.), Handbook of industrial and organizational psychology (pp. 1125-1172). Chicago: Rand McNally.

Peters, T. J., \& Waterman, R. H. (1982). In search of excellence. New York: Harper \& Row. 
Godson AHIABOR. The Impact of Corporate Culture on Productivity of Firms in Ghana: A Case of Vodafone Ghana

OF MANAGEMENT

IN THE $21^{\text {st }}$ CENTURY

Vol. 9, No. 3, 2014

182

Plakhotnik, M. S., \& Tonette, S. R. (2005). Organizational culture: A literature review of the AHRD 1994-2005 proceedings. Florida: Sage Publishers.

Schein, E. H. (1990). Organizational culture and leadership: A dynamic view. San Francisco: JosseyBass.

Taylor, W. (1991). The logic of global business: An interview with ABB's Percy Barnevik. Harvard Business Review, 69 (2), 90-106.

Turner, I. (1990). Strategy and organization. Manager Update, 1 (3), 193-206.

Advised by Constantin Bratianu, Academy of Economic Studies, Bucharest, Romania

Received: September 11, 2014

Accepted: December 18, 2014

Godson Ahiabor

Lecturer, Central University College, P.O. Box Ds 2310, Dansoman, Accra,

Ghana.

E-mail: gkahiabor@yahoo.com 